\title{
Anti-cancer effect of snake venom toxin through down regulation of AP-1 mediated PRDX6 expression
}

\author{
Hye Lim Lee ${ }^{1, *}$, Mi Hee Park ${ }^{1, *}$, Dong Ju Son ${ }^{1}$, Ho Sueb Song ${ }^{2}$, Jung Hyun Kim ${ }^{2}$, \\ Seong Cheol $\mathrm{Ko}^{2}$, Min Jong Song ${ }^{3}$, Won Hyoung $\mathrm{Lee}^{4}$, Joo Hee Yoon ${ }^{5}$, \\ Young Wan Ham ${ }^{6}$, Sang Bae Han ${ }^{1}$, Jin Tae Hong ${ }^{1}$ \\ ${ }^{1}$ College of Pharmacy, Medical Research Center, Chungbuk National University, Osong-eup, Heungduk-gu, Cheongju, \\ Chungbuk, Republic of Korea \\ ${ }^{2}$ Department of Acupuncture \& Moxibustion Medicine, College of Korean Medicine, Gachon University, Bokjeong-dong, \\ Sujeong-gu, Seongnam, Gyeonggii, Republic of Korea \\ ${ }^{3}$ Department of Obstetrics and Gynecology, Daejeon St. Mary's Hospital, College of Medicine, The Catholic University of \\ Korea, Jung-gu, Daejeon Republic of Korea \\ ${ }^{4}$ Department of Nuclear Medicine Chungbuk National University Hospital, Seowon, Cheongju, Chungbuk Republic of Korea \\ ${ }^{5}$ Department of Obstetrics and Gynecology, St. Vincent's Hospital, College of Medicine, The Catholic University of Korea, \\ Paldal-gu, Suwon, Gyeonggi-do, Republic of Korea \\ ${ }^{6}$ Department of Chemistry and Biochemistry, Brigham Young University, Provo, Utah, United States \\ *These authors have contributed equally to this work
}

Correspondence to:

Jin Tae Hong, e-mail: jinthong@chungbuk.ac.kr

Sang Bae Han, e-mail: shan@chungbuk.ac.kr

Keywords: snake venom toxin, apoptosis, PRDX6, AP-1, lung cancer

Received: April 05, $2015 \quad$ Accepted: May 20, $2015 \quad$ Published: June 01, 2015

\section{ABSTRACT}

Snake venom toxin (SVT) from Vipera lebetina turanica contains a mixture of different enzymes and proteins. Peroxiredoxin 6 (PRDX6) is known to be a stimulator of lung cancer cell growth. PRDX6 is a member of peroxidases, and has calciumindependent phospholipase A2 (iPLA2) activities. PRDX6 has an AP-1 binding site in its promoter region of the gene. Since AP-1 is implicated in tumor growth and PRDX6 expression, in the present study, we investigated whether SVT inhibits PRDX6, thereby preventing human lung cancer cell growth (A549 and NCI-H460) through inactivation of AP-1. A docking model study and pull down assay showed that SVT completely fits on the basic leucine zipper (bZIP) region of c-Fos of AP-1. SVT (0-10 $\mu \mathrm{g} / \mathrm{ml})$ inhibited lung cancer cell growth in a concentration dependent manner through induction of apoptotic cell death accompanied by induction of cleaved caspase-3, -8, -9, Bax, p21 and p53, but decreased CIAP and Bcl2 expression via inactivation of AP-1. In an xenograft in vivo model, SVT $(0.5 \mathrm{mg} / \mathrm{kg}$ and $1 \mathrm{mg} / \mathrm{kg})$ also inhibited tumor growth accompanied with the reduction of PRDX6 expression, but increased expression of proapoptotic proteins. These data indicate that SVT inhibits tumor growth via inhibition of PRDX6 activity through interaction with its transcription factor AP-1.

\section{INTRODUCTION}

Lung cancer remains the most lethal malignancy in the world. Despite improvements in surgical treatment, systemic therapy, and radiotherapy, the 5-year survival rate for all patients diagnosed with lung cancer remains between 15 and $20 \%$ [1]. Non-small cell lung cancer
(NSCLC) is the most common type of lung cancer, and can be further classified as nonsquamous carcinoma (including adenocarcinoma, which accounts for $40 \%$ of NSCLCs) and squamous NSCLC, which makes up 30\% of NSCLC cases [2-4]. Inhibitors of the epidermal growth factor receptor (EGFR) are used for the treatment of NSCLC [5]. In addition, other inhibitors such as miR-99a and heat 
shock protein 90 (HSP 90) have been also involved in lung tumor development. Down-regulation of miR-99a is significantly associated with last-stage and tumor metastasis in NSCLC patients. Further functional experiments found that overexpression of miR-99a inhibit cell proliferation, migration and invasion of NSCLC cells in vitro and tumor metastasis of NSCLC in vivo [6]. HSP 90 is of considerable interest because tumor cells and oncogenic proteins are acutely dependent on its activity, and the HSP90 inhibitor is currently being clinically tested against a wide array of tumor cell lines, including lung cancer cell lines [7]. A proteomics analysis study suggests that the expression of cytokeratine 8, Y-box binding protein 1 (YB-1), proliferating cell nuclear antigen (PCNA), non-metastatic protein 23 (Nm23) were also significant in lung cancer development [8].

PRDX6, a 1-Cys PRDX, is a bifunctional protein that acts both as glutathione peroxidase and calciumindependent phospholipase A2 (iPLA2) [9, 10]. The mammalian PRDXs family is composed of six members, PRDX1-6. PRDXs 1-5 have two catalytically active cysteines, while PRDX6 is the sole 1-Cys member PRDXs function together to detoxify ROS and thus provide cytoprotection from internal and external environmental stress [11, 12]. A lot of research about correlation to the occurrence of cancer and the PRDXs family has been performed. Recent studies reported elevated expression of PRDX1 in several human cancers, including esophagus [13], breast [14] and prostate [15]. PRDX2 levels are increased in cervical cancer [16], colon cancer $[17,18]$ and metatstaic breast cancer in lung [19]. PRDX3 levels are increased in prostate cancer [20], lung cancer [21], breast cancer [22] and hepatocellular caricinoma [23]. PRDX4 levels are increased in glioblastoma cell [24], prostate cancer [25] and lung cancer [26]. PRDX5 is expressed in the thyroid gland where it could act as an antioxidant [27]. PRDX6 expression was significantly higher in human tissue samples of TSCCs (tongue squamous cell carcinomas) compared with the 10 corresponding adjacent normal tissues [28]. Other studies have shown the strong expression of PRDX2 and 3 isoforms in cervical intraepithelial neoplasia and cervical cancer [16]. Previously, we found that PRDX6 accelerates lung tumor progression via increased GPx and iPLA2 activities [29]. We also found that overexpression of PRDX6 promotes lung tumor growth via increased glutathione peroxidase and iPLA2 activities through the upregulation of the activating protein-1 (AP-1) and Jun $\mathrm{N}$-terminal kinase (JNK) pathways [30].

The AP-1 complex is composed of homodimers of Jun family members (cJun, JunB and JunD), heterodi-mers of Jun and Fos (cFos, FosL1, FosL2, and FosB), or cAMP response element-binding protein (CREB)/activating transcription factor (ATF) family members [31, 32]. AP-1 stimulates genes involved in cancer cell invasion and metastasis, proliferation, differentiation, and survival $[33,34]$. Of NSCLC patients, the expression of AP-1 in
NSCLC was higher than that in normal lung tissues [35]. Recent studies reported that specific AP-1 blockade by the dominant negative c-Jun mutant, TAM67, inhibits the tumor number during the tumor promotion stage of lung tumorigenesis. Researchers used a transgenic mouse model directing conditional expression of TAM67 in lung epithelial cells to determine the effect of AP-1 inhibition on mouse lung tumorigenesis. [36]. Expression of Suppressor of AP-1, Regulated by IFN (SARI), as an AP-1 inhibitory protein expression in patients with NSCLC had a poor prognosis, and over-expression of SARI in A549 cells inhibited the growth and migration of these cells [37]. The human PRDX6, as an antioxidant enzyme, has an AP-1 binding sequence in the promoter region [38]. Thus, AP-1 is significant in the tumor preventing effect of PRDX6.

SVT of Vipera lebetina turanica is the substance derived from a natural product that has a diverse effects. SVT has an anti-inflammatory effect [39], anti-arthritic effect [40] and anti-cancer effect [41]. Previously, we demonstrated that SVT has an anti-cancer effect of prostate [42], ovarian [43], colon [44], lung cancer [45] and neroblostoma cell [46]. SVT is actually a group of basic peptides composed of 235 amino acids with six disulfide bonds formed by 12 cysteines [47] which binds to cysteine residues of target molecules. Our previous findings indicate SVT binds to the cysteines of NF- $\kappa B$ thereby blocking NF- $\kappa \mathrm{B}$ activities [48]. This binding inhibited the tumor promoting capacity in prostate cancer cells [42]. Our previous study also showed that cysteine residue (C47) of PRDX6 directly binds to thiacremonone blunting the lung tumor promoting effect of PRDX [49]. Thus, it is possible that SVT binds to the cysteine residue of its transcription factor AP-1 in PRDX6, and as a result, the inactivation of PRDX6 inhibits lung cancer cell growth.

However, cancer cell growth inhibitory effects and possible mechanism of SVT in lung cancers has not been studied yet. In the present study, we evaluated anti-tumor effects of SVT in lung cancer cells through blunting AP-1 activity of PRDX6.

\section{RESULTS}

\section{Effect of SVT on cell growth and apoptotic cell death in lung cancer cells}

To assess the inhibitory effect of SVT on cell growth of lung cancer cells; A549 and NCI-H460, we analyzed cell growth by MTT assay. Morphologic observation showed that the cells were gradually reduced in size and changed into a small round single cell shape with the treatment of SVT in A549 cells and NCI-H460 cells (Fig. 1A and 1B). The cells were treated with several concentrations of SVT $(1,5$ and $10 \mu \mathrm{g} / \mathrm{ml})$ for $72 \mathrm{hr}$. As shown in Fig. 1C and 1D, SVT inhibited growth of lung cancer cells in a concentration-dependent manner with 
A

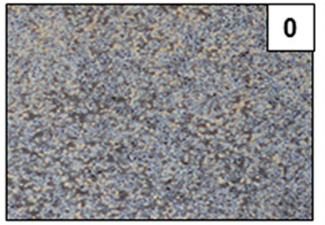

C

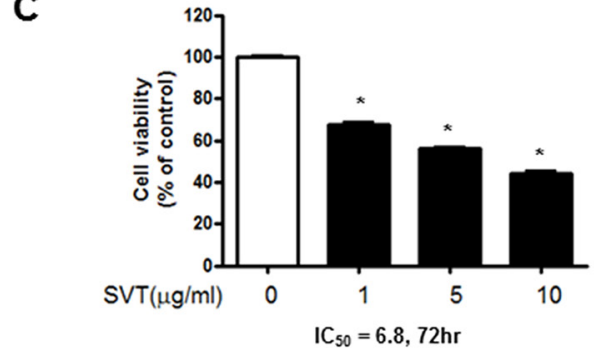

E
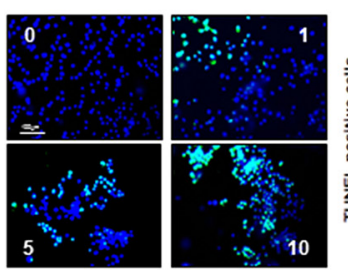

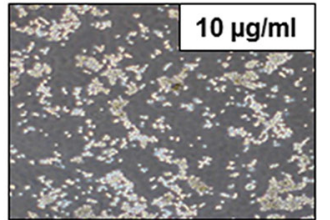

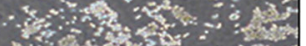

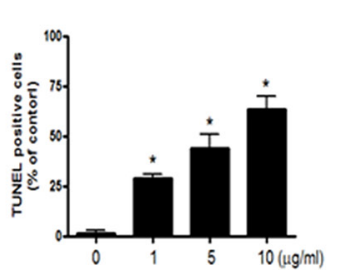

B

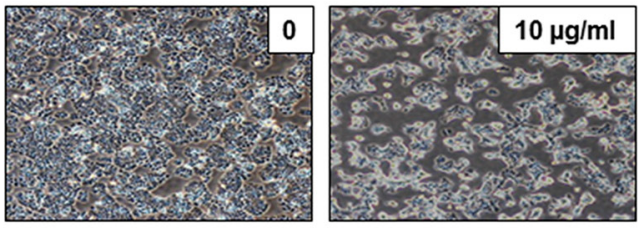

D

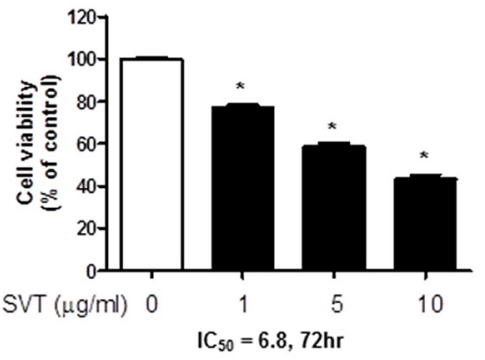

$\mathbf{F}$
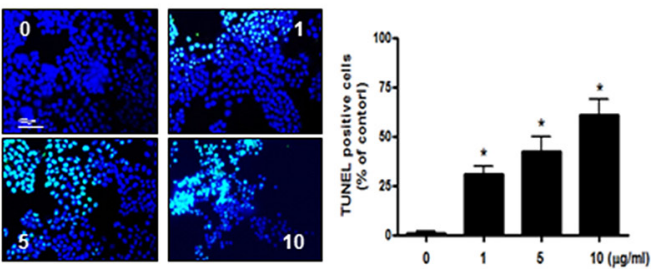

Figure 1: Effect of SVT on cell growth and apoptotic cell death in lung cancer cells. Concentration-dependent effect of SVT on the MTT viability assay in A549 and NCI-H460 after $24 \mathrm{hr}$ C and D. Morphologic observation with the treatment of SVT. A549 and NCI-H460 cells morphological changes were observed under phase contrast microscope $\mathbf{A}$ and $\mathbf{B}$. respectively). The data were expressed as the mean \pm S.D. of three experiments. $*(P \leq 0.05)$ indicates statistically significant differences from the control group. The lung cancer cells were treated with SVT for $24 \mathrm{hr}$, and then labeled with DAPI and TUNEL solution. Total number of cells in a given area was determined by using DAPI nuclear staining (fluorescent microscope). The green color in the fixed cells marks TUNEL-labeled cells. The apoptotic index was determined as the DAPI-stained TUNEL-positive cell number/total DAPI stained cell number (magnification, 200×) E and $\mathbf{F}$. Values were means \pm S.D. of three experiments. * $(P \leq 0.05)$ indicates statistically significant differences from the control cells.

$\mathrm{IC}_{50}$ value of $6.8 \mu \mathrm{g} / \mathrm{ml}$ in A549 cells, and $\mathrm{IC}_{50}$ values of $6.8 \mu \mathrm{g} / \mathrm{ml}$ in NCI-H460 cells, respectively. We performed DAPI staining followed by TUNEL staining assays, and then the double labeled cells were analyzed by a fluorescence microscope to determine the inhibition of cell growth by SVT was due to the induction of apoptotic cell death. Reversely, consistent with cell growth inhibitory effects, apoptotic cell death was significantly increased in SVT treated A549 and NCI-H460 lung cancer cells, respectively. The number of apoptotic cells (DAPIpositive TUNEL-stained cells) in A549 and NCI-H460 human lung cancer cell cultures was increased to about $62 \%$ and $73 \%$ of cells, respectively, at a concentration of $10 \mu \mathrm{g} / \mathrm{ml}$ (Fig. 1E and 1F).

\section{Structure of SVT and interaction between SVT and c-Fos of AP-1}

The interaction of SVT (Fig. 2A)-Sepharose 4B beads with cell lysate containing c-Fos protein was assessed using a pull-down assay. The interaction of SVTSepharose 4B beads with c-Fos of AP-1 was then detected by immunoblotting with anti-c-Fos antibody. The results indicated that tectochrysin interacted with cell lysates containing c-Fos from A549 cells (Fig. 2B). To identify the binding site of SVT to c-Fos of AP-1, we performed computational docking experiments with SVT and c-Fos of AP-1. The best binding mode indicates that SVT binds in the basic leucine zipper (bZIP) region of AP-1. The binding pocket is comprised of Gln180, Lys176, Asp174, Glu173, Asp170 and Gln166 (Fig. 2C) .

\section{Effect of SVT expression of apoptotic regulatory proteins}

The activation of cell death regulatory proteins including DRs, caspases-3, -8 and -9 as well as Bax, leads to apoptosis in cancer cells. To figure out the expression of cell death regulatory proteins by SVT, the expression of apoptotic proteins was investigated by Western blots. The expression of pro-apoptotic proteins, Bax and cleaved form of caspase- $3,-8,-9$, and p21 and p53 were increased by a treatment of SVT. However, the expression of PRDX6, Bcl2, and c-IAP1 were decreased by the treatment of SVT in a concentration dependent manner (Fig. 3A and 3B). 
A

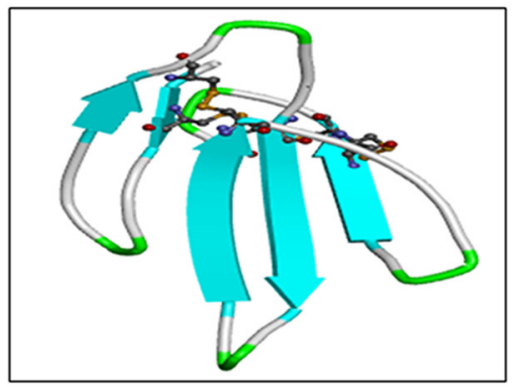

B

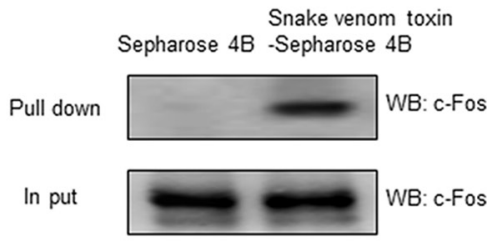

C

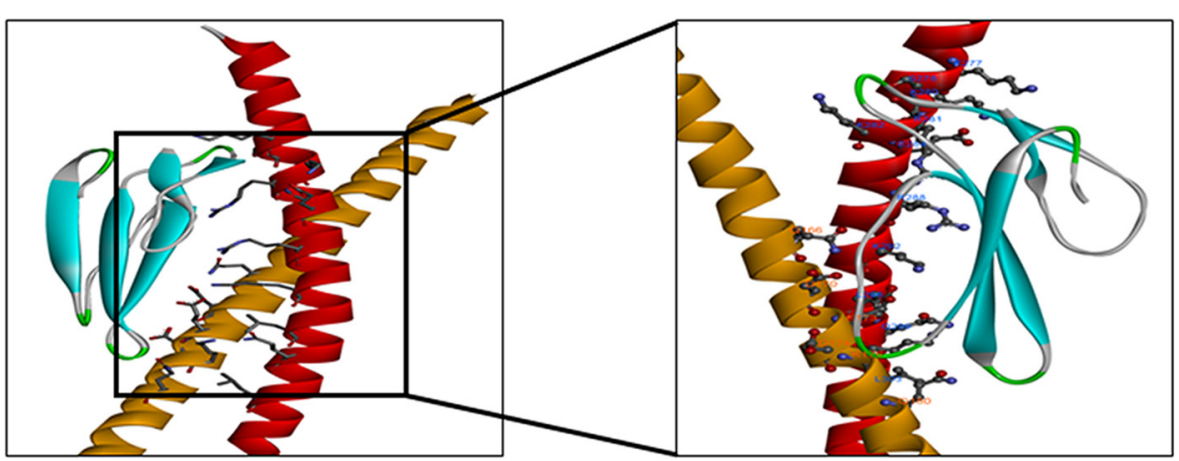

Figure 2: Structure of SVT and AP-1 and binding of SVT to c-Fos of AP-1. Structure of SVT of Vipera lebetina turanica. A. Structure of Cobrotoxin. B. Whole cell lysates of A549 were incubated with SVT-conjugated Sepharose 4B. After precipitation, the levels of bound c-Fos were monitored by Western blot analysis. C. Docking model of SVT with c-Fos. Molecular surface representation docking model of SVT with c-Fos. doi:10.1371/journal.pone.0091508.g001
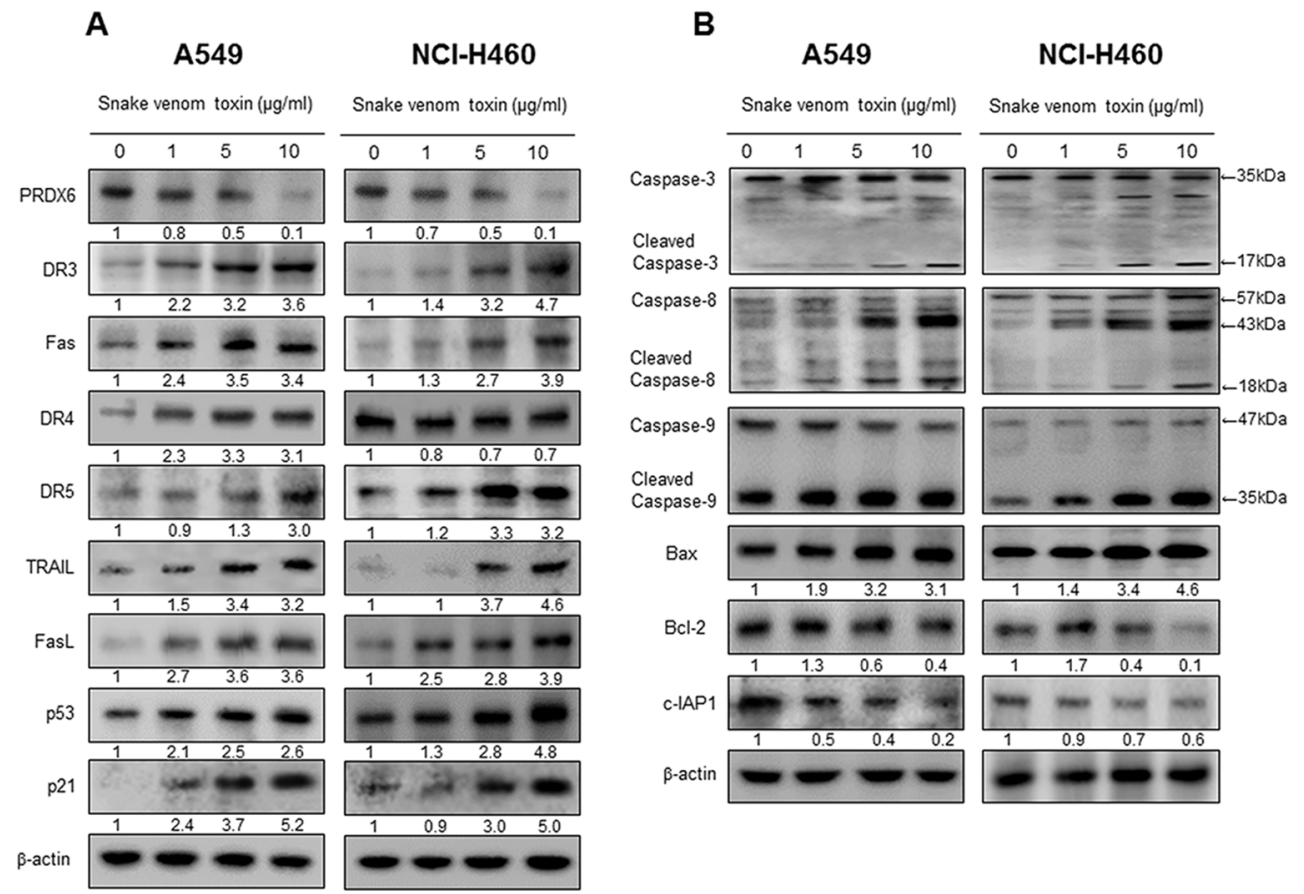

Figure 3: Effect of SVT expression of apoptotic regulatory proteins. Expression of apoptosis regulatory proteins related exntrinsic pathway was determined using Western blot analysis with the antibodies against PRDX6, DR3, DR4, DR5, FAS, FASL, TRAIL, Bax, Bcl-2, c-IAP1, p53, p21, Caspase-3, caspase-8, caspase-9, and $\beta$-actin. $\beta$-actin protein was used an internal control. Each band is representative for three experiments $\mathbf{A}$ and $\mathbf{B}$. 


\section{Effect of SVT on AP-1 activation}

We determined whether SVT can inhibit AP-1 DNA binding activity. Nuclear extracts from treated cells were prepared and assayed for AP-1 DNA binding by EMSA. Lung cancer cells have a strong AP-1 DNA binding activity, which was attenuated by the treatment of SVT in a concentration dependent manner (Fig. 4A and 4B). Consistent with the inhibitory effect on AP-1 activity, the expression in the nucleus protiens c-Jun and c-Fos and the cytosolic protiens c-Jun and c-Fos, components of AP-1, were also inhibited (Fig. 4C and 4D).

\section{Effect of SVT with AP-1 inhibitor (SR11302) and siRNA of c-Fos on the expression of PRDX6}

To further demonstrate the involvement of AP-1 pathway in SVT-induced lung cancer cell growth,

A

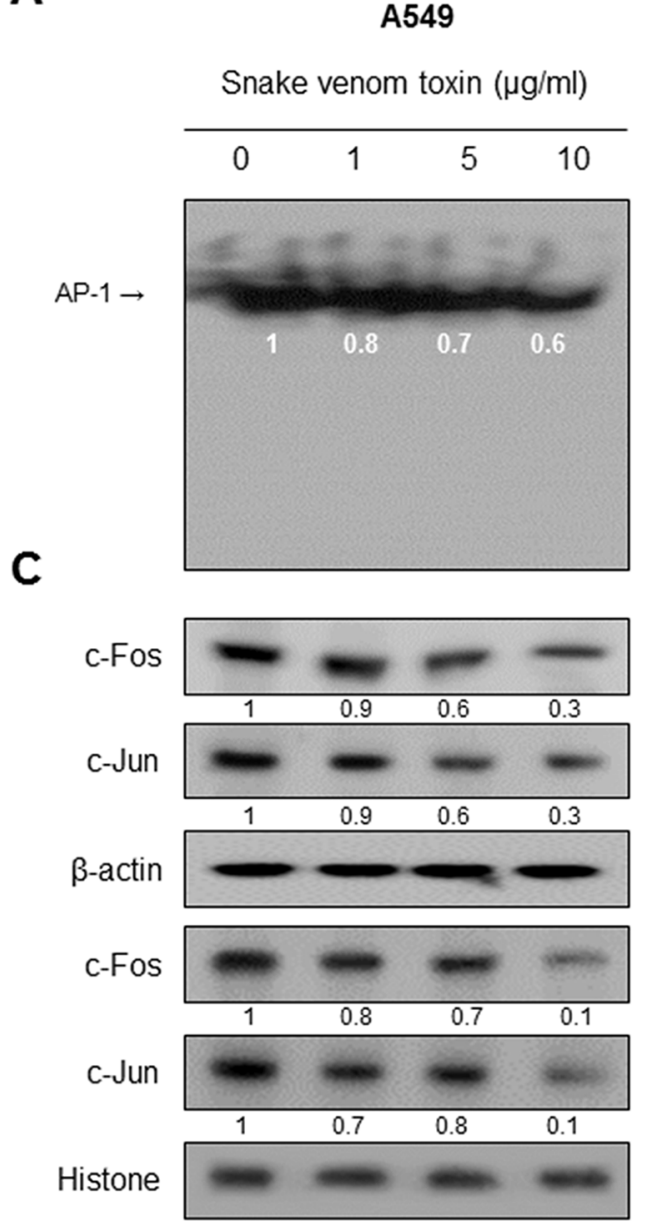

we compared the combination treatment of SVT and AP-1 inhibitor (SR11302, $10 \mu \mathrm{M}$ ) with SVT or AP-1 inhibitor alone. Cancer cells were pretreated with AP-1 inhibitor (SR11302, $10 \mu \mathrm{M}) 30 \mathrm{~min}$ prior to the treatment of SVT $(5 \mu \mathrm{g} / \mathrm{ml})$, and then assayed cell growth and PRDX6 expression. The combination treatment of SVT with AP-1 inhibitor greatly inhibited lung cancer cell growth compared to those by SVT or AP-1 inhibitor alone in both cancer cells (Fig. 5A). We also found that a much lower expression of iPLA2 (Fig. 5B) and expression of PRDX6 (Fig. 5C) occured by the combination treatment of SVT and AP-1 inhibitor. To further determine the relationship between PRDX6 expression and lung cancer cell growth inhibitory effect of SVT, we transfected A549 and NCI-H460 cells with c-Fos siRNA using a transfection agent. The cells were transfected with $100 \mathrm{nM}$ siRNA of c-Fos for $24 \mathrm{hr}$, and then treated with SVT $(10 \mu \mathrm{g} / \mathrm{ml})$ for another $24 \mathrm{hr}$. Knock down of c-Fos almost completely

B
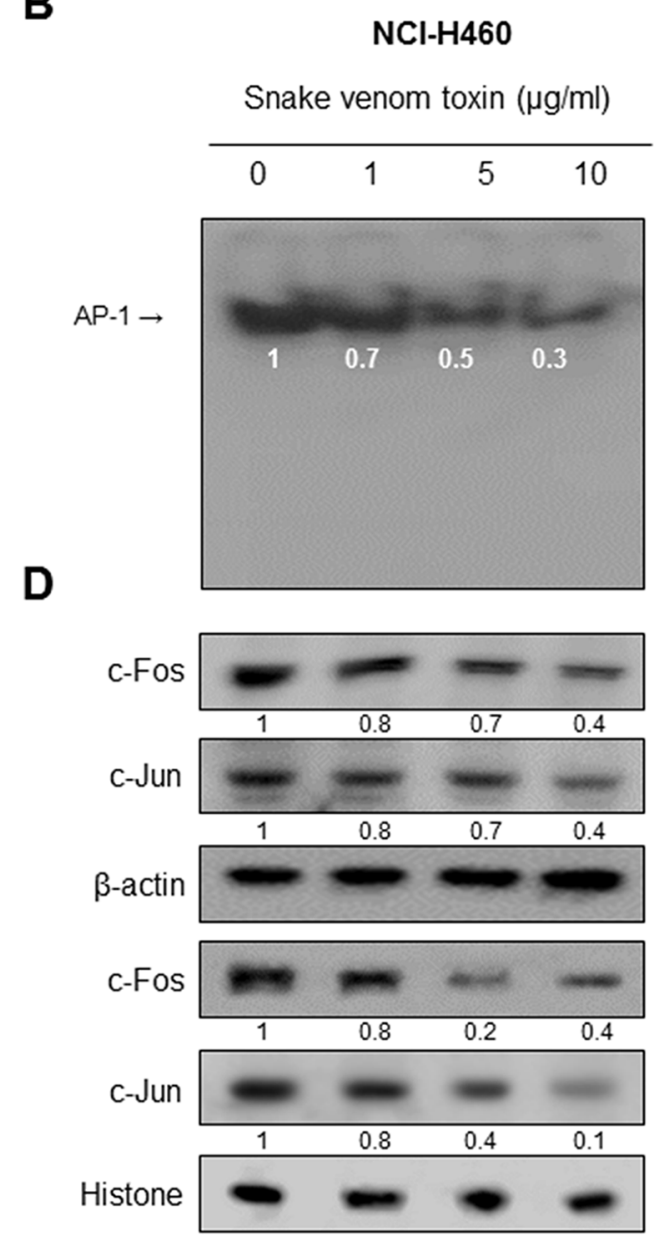

Figure 4: Effect of SVT on AP-1 activaion. Nuclear extract from lung cancer cells treated with SVT $(1,5$, and $10 \mu \mathrm{g} / \mathrm{ml})$ for $2 \mathrm{hr}$ was incubated in binding interaction of $\mathrm{P}^{32}$-end-labeled oligonucleotide containing the AP-1 sequence. The present EMSA results are representatives of three experiments $\mathbf{A}$ and $\mathbf{B}$. The cells treated with SVT $(1,5$ and $10 \mu \mathrm{g} / \mathrm{ml})$ for $2 \mathrm{hr}$ was incubated and were lysed, cytosolic proteins were used to determine the expression of c-Jun, c-Fos and $\beta$-actin (internal control) in lung cancer cells. Nuclear proteins were used to determine the expression of c-Jun, c-Fos and Histone (internal control) in lung cancer cells $\mathbf{C}$ and $\mathbf{D}$. Each band is representative for three experiments. 
A

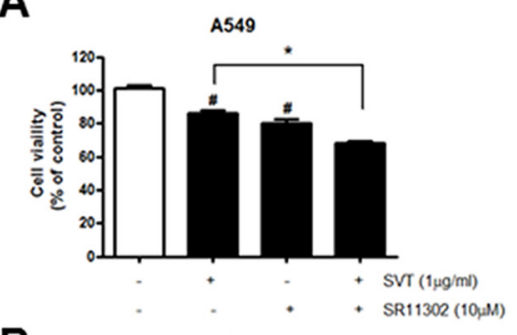

B

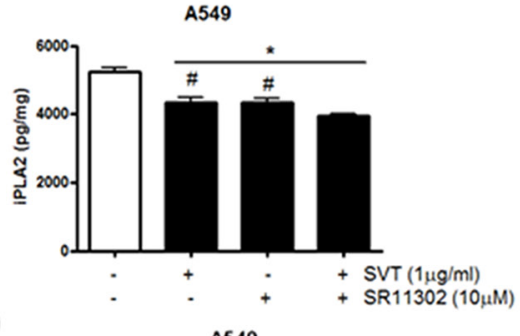

D

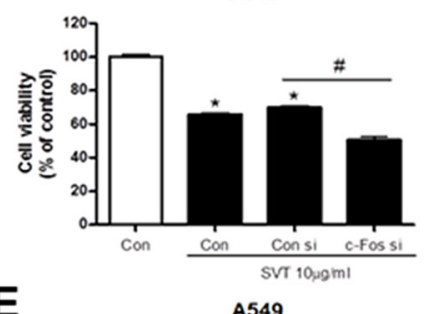

E

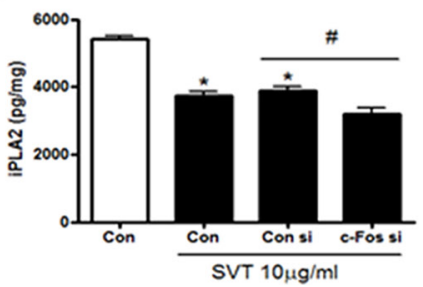

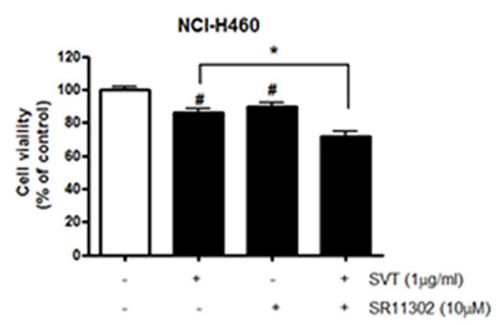

$\mathrm{NCl}-\mathrm{H} 460$

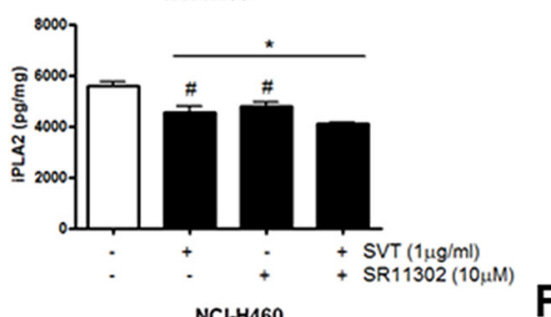

$\mathrm{NCl}-\mathrm{H} 460$

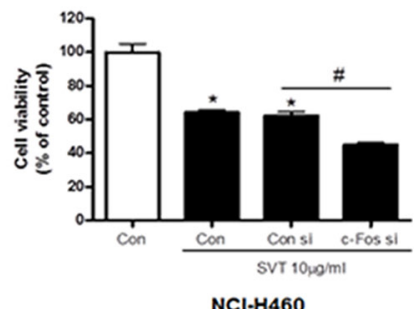

$\mathrm{NCl}-\mathrm{H} 460$

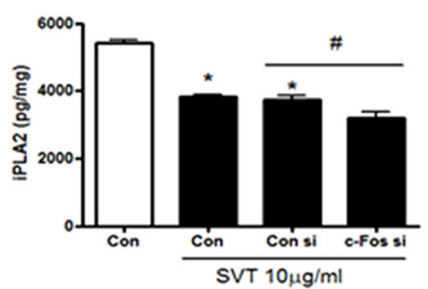

C

A549

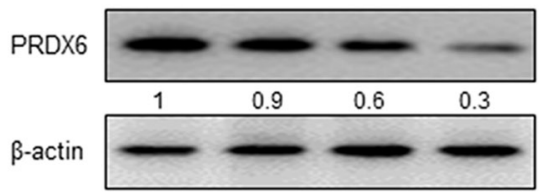

$\mathrm{NCl}-\mathrm{H} 460$

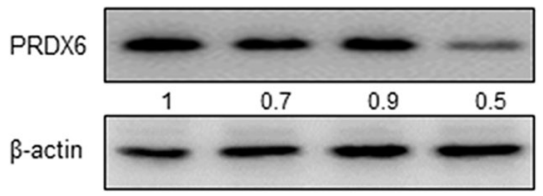

A549

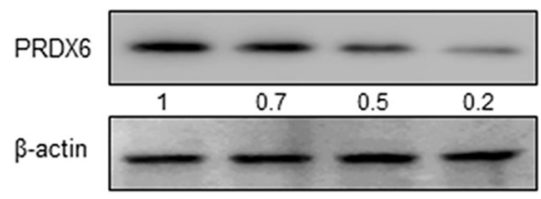

$\mathrm{NCl}-\mathrm{H} 460$

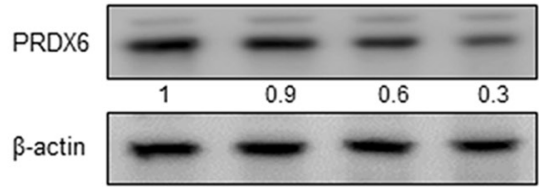

Figure 5: Effect of SVT with AP-1 inhibitor (SR11302) and siRNA of c-Fos on the expression of PRDX6. A549 and NCI-H460 cells were pretreated with AP-1 inhibitor (SR11302, $1 \mu \mathrm{M}$ ) for $30 \mathrm{~min}$, the media were removed, and the cells were exposed to SVT $(5 \mu \mathrm{g} / \mathrm{ml}$ ) for $24 \mathrm{hr}$ or $2 \mathrm{hr}$ A. Cell viability was determined by MTT assay as described in Materials and Methods. Expression of iPLA2 was detected by ELISA kit B. Then equal amounts of total proteins (20 $\mu \mathrm{g} / \mathrm{lane})$ were subjected to $12 \%$ SDS-PAGE. Expression of PRDX6 and $\beta$-actin was detected by Western blotting using specific antibodies. $\beta$-actin protein was used an internal control $\mathbf{C}$. The lung cancer cells were transfected with the c-Fos siRNA $(100 \mathrm{nM})$ for $24 \mathrm{hr}$, the cells were then and treated with SVT $(10 \mu \mathrm{gg} / \mathrm{ml})$ for $24 \mathrm{hr}$. After treatment, cell viability was measured by MTT assay D. Expression of iPLA2 was detected by ELISA kit E. Then equal amounts of total proteins $(20 \mu \mathrm{g} / \mathrm{lane})$ were subjected to $12 \%$ SDS-PAGE. Expression of PRDX6 and $\beta$-actin was detected by Western blotting using specific antibodies F. $\beta$-actin protein was used an internal control. Cell growths are means \pm S.D. of three exprements. ${ }^{*}(P \leq 0.05)$ indicates statistically significant differences from control cells. ${ }^{*}(P \leq 0.05)$ indicates statically significant differences from SVT treated group.

reversed the cell growth inhibitory effect of SVT in A549 and NCI-H460 (Fig. 5D).We also found a lower expression of iPLA2 (Fig. 5E) and expression of PRDX6 (Fig. 5F).

\section{SVT inhibited tumor growth in vivo xenograft}

To elucidate the anti-tumor effect of SVT in vivo, the tumor growth on lung cancer cell xenograft bearing nude mice following SVT $(0.5 \mathrm{mg} / \mathrm{kg}$ and $1 \mathrm{mg} / \mathrm{kg})$ treatments, was investigated. SVT $(0.5$ or $1 \mathrm{mg} / \mathrm{kg}$ injected intraperitoneally two times per every week for a period of 3 weeks) significantly inhibited tumor volume and tumor growth (Tumor volume and tumor weight, $30 \%$ or $40 \%$ over control by $1 \mathrm{mg} / \mathrm{kg} \mathrm{SVT}$ ) (Fig. 6A). Expression of pro-apoptotic proteins including cleavaged caspase- 3 was concomitantly increased, but expression of PRDX6 was inhibited (Fig. 6B). Expression of PCNA, PRDX6 and c-Fos were inhibited, but pro-apoptotic proteins, including cleavaged caspase-3, were concomitantly increased (Fig. 6C). iPLA2 activity was also inhibited by the treatment with SVT (Fig. 6D). AP-1 activity and cytosol of c-Jun and c-Fos and nucleus translocation of c-Jun and c-Fos were inhibited in tumor tissues by the treatment with SVT (Fig. 6E). 

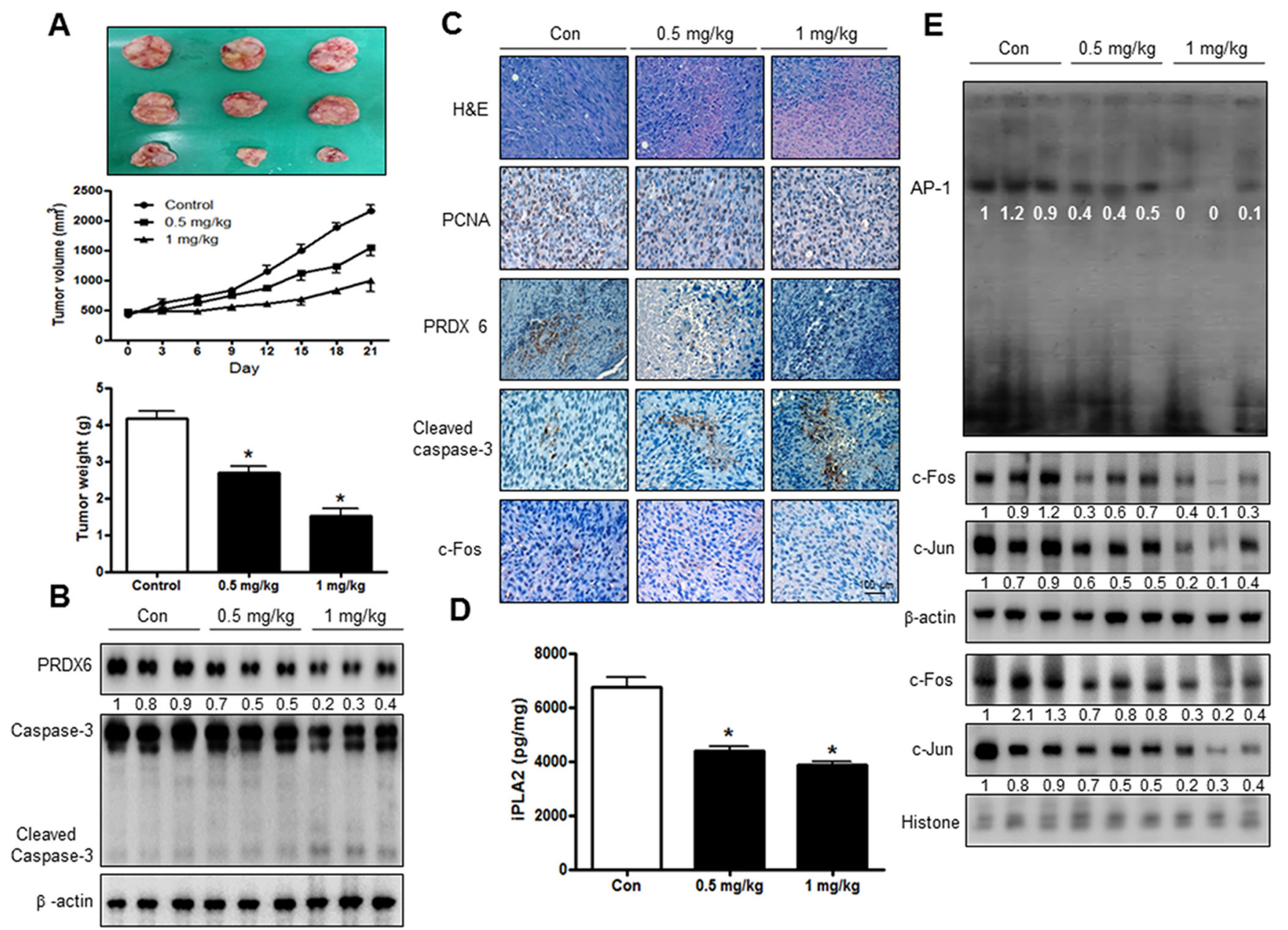

Figure 6: SVT inhibited tumor growth in vivo xenograft. Tumor volumes, weights, and images of normal mice A. The expression of PRDX6 and Caspase- 3 was detected by western blotting B. $\beta$-actin protein was used an internal control. Tumor sections of mice were analyzed by H\&E, PCNA, PRDX6, Caspase-3 and c-Fos by immunohistochemistry C. Expression of iPLA2 was detected by ELISA kit D. AP-1 activity in tumor tissue E. The resultant tissues were developed with DAB, and counterstained with hematoxylin. Scale bar indicates $50 \mathrm{~mm}$. $*(P \leq 0.05)$ indicates statistically significant differences from control cells.

\section{DISCUSSION}

In the present study, we found that SVT inhibited cell growth of human lung cancer cells; A549 and NCI-H460 through the inhibition of PRDX6 activity via interaction to AP-1. SVT has an anti-inflammatory effect [39], anti-arthritic effect [40] and anti-cancer effect [41]. Previously, we demonstrated that SVT has an anticancer effect of prostate [42], ovarian [43], colon [44] and neroblostoma cells [46]. Our present study further demonstrated SVT could be a useful compound to treat lung cancer.

Our present findings showed that SVT inhibited lung cancer cell growth through the inhibition of PRDX6 activity via interaction to AP-1. A lot of research has been performed to demonstrate the relevance between PRDXs and tumor growth. PRDX6 overexpression attenuates cisplatin-induced apoptosis in human ovarian cancer cells; SKOV-3 [50]. Suppression of PRDX6 in Hepa1-6 cells would increase susceptibility to peroxideinduced cell death [51]. Previously, we found that PRDX6 accelates lung tumor progression [29]. Many compounds showed their anti-tumor activity by modification of PRDXs activity. Dioscin induces esophageal cancer cell apoptosis through downregulation of PRDX1 and 6 [13]. Multiple myeloma cell growth was selectively and significantly reduced by (-)-Epigallocatechin 3-gallate through the downregulation of PRDXs [52]. 4-amino-5(4-chlorophenyl)-7-(t-butyl)pyrazolo[3, 4-d]pyrimidine (PP2) induces apoptosis and decreases the expression of PRDX3 in human breast cancer MCF-7 cells [22]. We also found that thiacremonone inhibited lung tumor growth in PRDX6 overexpressed transgenic mice through downregulation of PRDX6 [49]. These data suggest that downregulation of PRDX6 could be significant for SVTinduced lung cancer cell growth inhibition. 
AP-1 stimulates genes involved in invasion and metastasis, proliferation, differentiation, and survival as well as angiogenesis [33, 34]. Of NSCLC patients, the expression of AP-1 in NSCLC was higher than that in normal lung tissues [35]. It was reported that inhibition of AP-1 by conditional expression of the dominant-negative c-Jun mutant in lung epithelial cells decreased tumor number and overall lung tumor burden in chemically induced mouse lung tumor models [36]. It was reported that the nucleotide sequence of the PRDX1 gene has potential AP-1 sites [38], and PRDX1 promoter region binds JunB and c-Fos of AP-1 [53]. Most studies related to identification of responsive elements in the PRDX6 gene promoter have described several redox-active transcription factors including a AP-1, suggesting that PRDX6 gene is also subjected to a complex transcriptional regulation through AP-1 [54]. Other studies also reported that promoter region of PRDX6 contains nucleotide sequence of AP-1 [38]. Previously, we found overexpression of PRDX6 promotes lung tumor growth via increased glutathione peroxidase and iPLA2 activities through the upregulation of the AP-1 and JNK pathways [30]. Knockdown of PRDX1 or PRDX4 significantly reduced the activation of c-Jun and thus repressed AP-1 mediated promoter activity, which may contribute to the changes of lung cancer cell phenotype [55]. Our previous study also found that higher lung tumor growth in PRDX6overexpressing transgenic mice was associated with an increase in AP-1 DNA-binding activity [30]. Thus, inhibition of AP-1 by SVT could be significant for reduced PRDX6 activity, and thus decreased lung cancer cell growth. Our present results showed that expression of PRDX6 via inactivation of AP-1 in A549 and NCI-H460 lung cancer cell were decreased. However, treatment of c-Fos siRNA in A549 and NCI-H460 reversed SVTinduced lung cancer cell growth inhibition. We also found that PRDX6 expression was significantly lower in the SVT treated cultured human lung cancer cells as wells as xenograft tumor tissues. Lower expression of PRDX6, iPLA2 and greater cell growth inhibition occured in the combination treatment of AP-1 inhibitor (SR11302, $10 \mu \mathrm{M}$ ) with SVT compared to those by AP-1 inhibitor or SVT alone. Through the pull-down assay using SVTagarose bead, we found that SVT bound with cell lysates containing c-Fos from human A549 lung cancer cells. We also found a direct interaction of SVT with c-Fos of AP-1 by the docking experiment. Other studies demonstrated that direct interaction of cyclopentenone 15-deoxy$\beta^{12,14}$-prostaglandin $\mathrm{J}_{2}\left(15 \mathrm{~d}-\mathrm{PGJ}_{2}\right)$ with 269 cysteine of AP-1 protein, and thus contribute to the complex effects of $15 \mathrm{~d}_{-} \mathrm{PGJ}_{2}$ on the cellular response to proinflammatory agents [56]. Arylstibonic acid NSC13746 binds specifically to c-Fos/JunD dimer of B-ZIP proteins at micromolar concentrations and can inhibit their DNA-binding activity both in vitro and in vivo [57]. Expression in the mouse epidermis of A-Fos, a dominant negative form that inhibits AP-1 DNA binding, converts papillomas into benign sebaceous adenomas that are not able to convert into carcinomas [58]. In in vivo study with A549 xenograft bearing mice, treatment of SVT $(0.5 \mathrm{mg} / \mathrm{kg}$ and $1 \mathrm{mg} / \mathrm{kg}$ injected intraperitoneally twice a week for 3 weeks) significantly inhibited tumor growth by approximately $50-60 \%$. The immunohistochemistry analysis of tumor section by $\mathrm{H} \& \mathrm{E}$, and by proliferation antigens against PCNA staining revealed that SVT inhibited tumor growth. In addition, our data also showed that SVT inhibited expression of PRDX 6 and AP-1 activity in lung tumor tissues. Also, our data showed that SVT inhibited expression of AP-1 accompanied with inhibition of expression of iPLA2 in lung tumor tissues. Moreover, expression of proapoptotic proteins, cleaved form of caspase-3 and Bax, was increased and antiapoptotic protein, but expression of $\mathrm{Bcl} 2$ was decreased by treatment of SVT. These data suggest that interaction of SVT with AP-1 block transcription of PRDX6 thus inhibiting PRDX6 could be implicated for lung tumor growth inhibition.

Snake venoms contain complex mixtures of pharmacologically active peptides and proteins and thus have a variety of pharmacological effects. Most significant effect is its anti-inflammatory effect through inhibition of NF- $\kappa \mathrm{B}$ activities and its production of IL- $1 \beta$, TNF- $\alpha$, iNOS and CAM-1 [39]. It has anti-arthritic effect showing significant restoration in paw \& ankle volume, paw weight, urinary hydroxyproline, glucosamine, serum ACP, ALP and IL-10 level by SVT treatment [40]. A recent study showed a protective effect of SVT against LPS-induced septic shock. Survival rate was significantly higher in SVT-treated rats, compared to that of non-treated septic rats. Furthermore, SVT treatment also significantly reduced LPS-associated TNF- $\alpha$ and LDH [59]. In addition, SVT has anti-tumor effects. SVT inhibited the proliferation, altered the cell cycle and enhanced the induction of apoptosis of breast cancer cells by increasing the activities of caspase-3, caspase- 8 and caspase-9. Moreover, SVT sensitized the primary breast cancer cells to growth arrest and apoptosis by increasing the generation of free radicals, including reactive oxygen species (ROS), hydroperoxide and nitric oxide [60]. In our recent study, the anti-cancer effect of SVT in cervical cancer via increase of death receptor 3 and 5 and inactivation of $\mathrm{NF}-\kappa \mathrm{B}$ was demonstrated [61]. It was known that the $\mathrm{LD}_{50}$ value for SVT in mice is $2.5 \mathrm{mg} / \mathrm{kg}$ [62]. In a previous study [61] and in the present study, we observed that SVT $(1 \mathrm{mg} / \mathrm{kg})$ did not induce any serious health problems, such as eruption, swelling, weight loss, or death in the animals. Thus, the dosage of SVT for cancer treatment could be safe enough to develop as a drug. In conclusion, our result that natural toxin SVT could be useful as an anti-lung cancer agent through inhibiton of PRDX6 by the interaction with AP-1 which inhibited expression of PRDX6. 


\section{MATERIALS AND METHODS}

\section{Materials}

Snake venom toxin from Vipera lebetina turanica was purchased from Sigma (St. Louis, MO). SR11302 was purchased from Tocris (Bristol, UK).

\section{Cell culture}

The A549 and NCI-H460 lung cancer cell lines were obtained from American Type Culture Collection (ATCC). Cells were cultured in RPMI 1640 (Gibco, Life Technologies, Grand Island, NY) medium supplemented with $10 \%$ heat inactivated fetal bovine serum (FBS) and 100 units $/ \mathrm{mL}$ penicillin, $100 \mu \mathrm{g} / \mathrm{mL}$ streptomycin (Invitrogen). Cell cultures were then maintained in an incubator within a humidified atmosphere of $5 \%$ $\mathrm{CO}_{2}$ at $37^{\circ} \mathrm{C}$.

\section{Cell growth assay}

Lung cancer cells, A549 and NCI-H460 cells, were plated in 96-well plates, and subsequently treated with SVT $0,1,5,10 \mu \mathrm{g} / \mathrm{mL}$ for $24 \mathrm{hr}$. After treatment, cell viability was measured by MTT [3-(4, 5-Dimethylthiazol2-yl)-2, 5-Diphenyltetrazolium Bromide] assay (Sigma Aldrich, St. Louis, MO) according to the manufacturer's instructions. Briefly, MTT $(5 \mathrm{mg} / \mathrm{mL})$ was added and plates were incubated at $37^{\circ} \mathrm{C}$ for $4 \mathrm{hr}$ before $100 \mu \mathrm{L}$ dimethyl sulfoxide (DMSO) was added to each well. Finally, the absorbance of each well was read at a wavelength of $540 \mathrm{~nm}$ using a microplate reader.

\section{Evaluation of apoptotic cell death}

TUNEL assay was performed by using the DeadEnd $^{\mathrm{TM}}$ Fluorometric TUNEL System (Promega, Madison, Wisconsin, USA) for in situ detection of apoptotic cells, according to the manufacturer's instructions. Lung cancer cells $\left(2 \times 10^{4}\right.$ cells/well $)$ were cultured on 8-chamber slides, after cells were treated with SVT. The cells were washed with PBS and fixed by incubation in 4\% paraformaldehyde in PBS for $20 \mathrm{~min}$ at room temperature. Membrane was permeabilized by exposure to $0.1 \%$ Triton X-100 in PBS for $5 \mathrm{~min}$ at room temperature. For DAPI staining, slides were incubated for $15 \mathrm{~min}$ at room temperature in the dark with a mounting medium for fluorescence containing DAPI (Vector Laboratories, Inc., Burlingame, CA). The cells were then observed through a fluorescence microscope (Leica Microsystems AG, Wetzlar, Germany). The total number of cells in a given area was determined by using DAPI and TUNEL staining. The apoptotic index was determined as the number of DAPI-stained TUNEL-positive cells divided by the total number of cells counted $\times 100$.

\section{Western blotting}

Lung cancer cells treated with SVT $(0 \sim 10 \mu \mathrm{g} / \mathrm{mL})$ for $24 \mathrm{hr}$ were homogenized with a protein extraction solution (PRO-PREPTM, Intron Biotechnology), and lysed for $60 \mathrm{~min}$ incubation on ice. The cell lysate was centrifuged at $15,000 \mathrm{rpm}$ for $15 \mathrm{~min}$ at $4^{\circ} \mathrm{C}$. Equal amount of proteins $(40 \mu \mathrm{g})$ were separated on a SDS/12\%-polyacrylamide gel, and then transferred to a polyvinylidene difluoride (PVDF) membrane (GE Water and Process technologies). Blots were blocked for $1 \mathrm{~h}$ at room temperature with $5 \%(\mathrm{w} / \mathrm{v})$ non-fat dried milk in TrisBuffered Saline Tween-20 [TBST: $10 \mathrm{mM}$ Tris (pH 8.0) and $150 \mathrm{mM} \mathrm{NaCl}$ solution containing $0.05 \%$ Tween-20]. After a short washing in TBST, the membranes were immunoblotted with the following primary antibodies: caspase-3, caspase-9, caspase-8, c-IAP1 and Bcl-2 (1:1000 dilutions; Cell Signaling, Beverly, MA) and c-Jun, c-fos, p21, p53, DR3, DR4, DR6, Fas, TRAIL, Fas Ligand and (1:2000 dilutions; Santa Cruz Biotechnology, Santa Cruz, CA) and DR5, PRDX 6 (1:1000 dilutions; Abcam, Cambridge, UK) The blots were performed using specific antibodies followed by second antibodies and visualization by a chemiluminescence (ECL) detection system.

\section{Electro mobility shift assay}

The DNA binding activity of NF- $\mathrm{BB}$ was determined using an electrophoretic mobility shift assay (EMSA) performed according to the manufacturer's recommendations (Promega). In short, A549 and NCI-H460 cells were cultured on 100-mm culture dishes. After treatment with SVT for $2 \mathrm{hr}$, the cells were washed twice with PBS, followed by the addition of $1 \mathrm{ml}$ of phosphate buffered saline (PBS), and then the cells were scraped into a cold Eppendorf tube. Nuclear extracts were prepared and processed for EMSA as previously described. The relative densities of the DNA-protein binding bands were scanned by densitometry using MyImage (SLB), and quantified by Labworks 4.0 software (UVP, Inc., Upland, CA).

\section{Transfection of siRNA}

Lung cancer cells $\left(1 \times 10^{4}\right.$ cells/well $)$ were plated in 96-well plates and transiently transfected with c-Fos siRNA, using a mixture of siRNA and the WellFect-EX PLUS reagent in OPTI-MEN, according to the manufacturer's specification (WelGENE, Seoul, Korea). The transfected cells were treated with $10 \mu \mathrm{g} / \mathrm{ml} \mathrm{SVT}$ for $24 \mathrm{hr}$ or $1 \mathrm{hr}$ and then used for detecting cell viability and protein expression (1 hr culture) and AP-1 activation (1 hr culture).

\section{Docking procedure}

The docking of AP-1 transcription factor with cobrotoxin was performed using a rigid-body docking 
program ZDOCK 3.0.2 on ZDOCK server (http:// zdock.umassmed.edu) [63]. ZDOCK server allows easy and fast production of structural models of proteinprotein complexes. AP-1 transcription factor from PDB ID:1FOS was used for the docking. Only one set of fosjun heterodimer was selected and the duplex DNA bound to fos-jun heterodimer was not included in the docking experiments to allow full search of binding interface for the other protein counterpart. Only one monomer of Cobrotoxin was selected from PDB ID: 1V6P. Docking experiments were performed without selection or blocking of residues.

\section{Pull down assay}

SVT was conjugated with cyanogen bromide (CNBr)-activated Sepharose 4B (Sigma-Aldrich, St. Louis, $\mathrm{MO})$. Briefly, SVT (1 mg) was dissolved in $1 \mathrm{ml}$ of coupling buffer $\left(0.1 \mathrm{M} \mathrm{NaHCO}_{3}\right.$ and $0.5 \mathrm{M} \mathrm{NaCl}$, pH 10. The CNBractivated Sepharose 4B was swelled and washed in $1 \mathrm{mM}$ $\mathrm{HCl}$ through a sintered glass filter, then washed with the coupling buffer. CNBr-activated Sepharose 4B beads were added to the SVT-containing coupling buffer and incubated at $4^{\circ} \mathrm{C}$ for $24 \mathrm{hr}$. The SVT-conjugated Sepharose 4B was washed with three cycles of alternating $\mathrm{pH}$ wash buffers (buffer 1, $0.1 \mathrm{M}$ acetate and $0.5 \mathrm{M} \mathrm{NaCl}, \mathrm{pH} 4.0$; buffer 2, 0.1 M Tris- $\mathrm{HCl}$ and $0.5 \mathrm{M} \mathrm{NaCl}, \mathrm{pH}$ 8.0). SVTconjugated beads were then equilibrated with a binding buffer (0.05 M Tris- $\mathrm{HCl}$ and $0.15 \mathrm{M} \mathrm{NaCl}, \mathrm{pH} 7.5)$. The control unconjugated CNBr-activated Sepharose 4B beads were prepared as described above in the absence of SVT. The cell lysate was mixed with SVT conjugated Sepharose $4 \mathrm{~B}$ or Sepharose $4 \mathrm{~B}$ at $4^{\circ} \mathrm{C}$ for $24 \mathrm{hr}$. The beads were then washed three times with TBST. The bound proteins were eluted with SDS loading buffer. The proteins were then resolved by SDS-PAGE followed by immunoblotting with antibodies against c-Fos (1:2000 dilutions; Santa Cruz Biotechnology, Santa Cruz, CA).

\section{Measurement of iPLA2}

Lysate of tumor tissue were used. Lysate of tumor tissue were obtained through protein extraction buffer containing protease inhibitor. iPLA2 levels were determined using each specific ELISA Kit (Cloud Clone Corp.). In brief, $100 \mu \mathrm{l}$ of sample was added into a precoated plate and incubated overnight at $4{ }^{\circ} \mathrm{C}$. After washing each well of the precoated plate with a washing buffer, $100 \mu \mathrm{l}$ of labeled antibody solution was added, and the mixture was incubated for $1 \mathrm{hr}$ at $4^{\circ} \mathrm{C}$ in the dark. After washing, chromogen was added, and the mixture was incubated for $30 \mathrm{~min}$ at room temperature in the dark. Finally, the resulting color was assayed at $450 \mathrm{~nm}$ using a microplate absorbance reader (Sunrise ${ }^{\mathrm{TM}}$, Tecan, Switzerland) after adding stop solution.

\section{Animal experiment}

To conduct in vivo studies, male $\mathrm{BALB} / \mathrm{c}$ nude mice (aged 6-7 weeks, weighing 20-25 g) were used. Nude mice were housed under specific pathogen free conditions according to the guidelines of the Animal Care Committee at the Chungbuk National University (CBNU-278-11-01). On day 0, A549 cells in PBS $\left(2 \times 10^{7}\right.$ tumor cells/ $\left.0.1 \mathrm{ml} \mathrm{PBS/ani-mals}\right)$ were injected subcutaneously into nude mice. The mice were divided into three groups $(n=6)$. SVT $(0.5 \mathrm{mg} / \mathrm{kg}$ and $1 \mathrm{mg} / \mathrm{kg}$ ) was administrated intraperitoneally twice per week for 3 weeks to mice with tumors ranging from 100 to $300 \mathrm{~mm}^{3}$. Tumor volumes were estimated by the formula: length $(\mathrm{mm}) \times$ width $(\mathrm{mm}) \times$ height $(\mathrm{mm}) / 2$ at the end of experiment.

\section{Immunohistochemistry}

All tissues were fixed in 4\% paraformaldehyde and cut into $4 \mu \mathrm{m}$ sections using a freezing microtome. The sections were stained with hematoxylin and eosin (H\&E) for pathological examination. For immunohistological staining, tumor sections were incubated in primary antibody. After rinse in phosphate buffered saline (PBS), the sections were subject to incubation in biotinylated secondary antibody. After the slides were washed and developed with DAB, the slides were counterstained with hematoxylin, mounted in aqua-mount, and evaluated on a light microscope (Olympus, Tokyo, Japan). Sections were dehydrated in a series of graded alcohols, cleared in xylene and coverslipped using Permount (Fisher Scientific, Suwanee, GA).

\section{Statistical analysis}

The data were analyzed using the GraphPad Prism 4 ver. 4.03 software (GraphPad Software). Data were presented as mean \pm S.D. The differences in all data were assessed by one-way analysis of variance. When the $p$ value in the ANOVA test indicated statistical significance, the differences were assessed by the Dunnett's test. A value of $p \leq 0.05$ was considered to be statistically significant.

\section{ACKNOWLEDGMENTS}

This work was supported by the National Research Foundation of Korea (NRF) Grant by the Korea government (MEST; MRC, 2008-0062275).

\section{CONFLICTS OF INTEREST}

The authors declare that they have no conflict of interest. 


\section{REFERENCES}

1. Korpanty GJ, Graham DM, Vincent MD, Leighl NB. Biomarkers That Currently Affect Clinical Practice in Lung Cancer: EGFR, ALK, MET, ROS-1, and KRAS. Frontiers in oncology. 2014; 4:204.

2. Piperdi B, Merla A, Perez-Soler R. Targeting angiogenesis in squamous non-small cell lung cancer. Drugs. 2014; 74:403-413.

3. Tang S, Pan Y, Wang Y, Hu L, Cao S, Chu M, Dai J, Shu Y, Xu L, Chen J, Jin G, Hu Z, Ma H, Shen H. Genome-wide Association Study of Survival in Early-stage Non-Small Cell Lung Cancer. Annals of surgical oncology. 2014; 22:630-35.

4. Zhang Y, Yang Q, Wang S. MicroRNAs: a new key in lung cancer. Cancer Chemother Pharmacol. 2014; 74:1105-11.

5. Emelyanova M, Arkhipova K, Mazurenko N, Chudinov A, Demidova I, Zborovskaya I, Lyubchenko L, Zasedatelev A, Nasedkina T. Sensitive Genotyping of Somatic Mutations in the EGFR, KRAS, PIK3CA, BRAF Genes from NSCLC Patients Using Hydrogel Biochips. Appl Immunohistochem Mol Morphol. 2015; 23:255-65.

6. Yu S, Zhang C, Deng F, Zhang Y. miR-99a suppresses the metastasis of human non-small cell lung cancer cells by targeting AKT1 signaling pathway. J Cell Biochem. 2015; 116:268-76.

7. Graham B, Curry J, Smyth T, Fazal L, Feltell R, Harada I, Coyle J, Williams B, Reule M, Angove H, Cross DM, Lyons J, Wallis NG, Thompson NT. The heat shock protein 90 inhibitor, AT13387, displays a long duration of action in vitro and in vivo in non-small cell lung cancer. Cancer science. 2012; 103:522-527.

8. Liu Y, Chen Q, Zhang JT. Tumor suppressor gene 14-3-3 sigma is down-regulated whereas the proto-oncogene translation elongation factor 1delta is up-regulated in non-small cell lung cancers as identified by proteomic profiling. Journal of proteome research. 2004; $3: 728-735$.

9. Manevich Y, Fisher AB. Peroxiredoxin 6, a 1-Cys peroxiredoxin, functions in antioxidant defense and lung phospholipid metabolism. Free radical biology \& medicine. 2005; 38:1422-1432.

10. Chowdhury I, Fisher AB, Christofidou-Solomidou M, Gao L, Tao JQ, Sorokina EM, Lien YC, Bates SR, Feinstein SI. Keratinocyte growth factor and glucocorticoid induction of human peroxiredoxin 6 gene expression occur by independent mechanisms that are synergistic. Antioxidants \& redox signaling. 2014; 20:391-402.

11. Bhabak KP, Mugesh G. Functional mimics of glutathione peroxidase: bioinspired synthetic antioxidants. Accounts of chemical research. 2010; 43:1408-1419.

12. Fatma N, Kubo E, Sharma P, Beier DR, Singh DP. Impaired homeostasis and phenotypic abnormalities in Prdx6-/-mice lens epithelial cells by reactive oxygen species: increased expression and activation of TGFbeta. Cell death and differentiation. 2005; 12:734-750.

13. Wang Z, Cheng Y, Wang N, Wang DM, Li YW, Han F, Shen JG, Yang de P, Guan XY, Chen JP. Dioscin induces cancer cell apoptosis through elevated oxidative stress mediated by downregulation of peroxiredoxins. Cancer biology \& therapy. 2012; 13:138-147.

14. Goncalves K, Sullivan K, Phelan S. Differential expression and function of peroxiredoxin 1 and peroxiredoxin 6 in cancerous MCF-7 and noncancerous MCF-10A breast epithelial cells. Cancer investigation. 2012; 30:38-47.

15. Riddell JR, Bshara W, Moser MT, Spernyak JA, Foster BA, Gollnick SO. Peroxiredoxin 1 controls prostate cancer growth through Toll-like receptor 4-dependent regulation of tumor vasculature. Cancer research. 2011; 71:1637-1646.

16. Kim K, Yu M, Han S, Oh I, Choi YJ, Kim S, Yoon K, Jung M, Choe W. Expression of human peroxiredoxin isoforms in response to cervical carcinogenesis. Oncology reports. 2009; 21:1391-1396.

17. Lu W, Fu Z, Wang H, Feng J, Wei J, Guo J. Peroxiredoxin 2 is upregulated in colorectal cancer and contributes to colorectal cancer cells' survival by protecting cells from oxidative stress. Molecular and cellular biochemistry. 2014; 387:261-270.

18. Levic K, Bulut O. [Transanal minimally invasive surgery for distal rectal cancer treatment.]. Ugeskrift for laeger. $2014 ; 176$.

19. Stresing V, Baltziskueta E, Rubio N, Blanco J, Arriba MC, Valls J, Janier M, Clezardin P, Sanz-Pamplona R, Nieva C, Marro M, Petrov D, Sierra A. Peroxiredoxin 2 specifically regulates the oxidative and metabolic stress response of human metastatic breast cancer cells in lungs. Oncogene. 2013; 32:724-735.

20. Whitaker HC, Patel D, Howat WJ, Warren AY, Kay JD, Sangan T, Marioni JC, Mitchell J, Aldridge S, Luxton HJ, Massie C, Lynch AG, Neal DE. Peroxiredoxin-3 is overexpressed in prostate cancer and promotes cancer cell survival by protecting cells from oxidative stress. British journal of cancer. 2013; 109:983-993.

21. Kim YS, Lee HL, Lee KB, Park JH, Chung WY, Lee KS, Sheen SS, Park KJ, Hwang SC. Nuclear factor E2-related factor 2 dependent overexpression of sulfiredoxin and peroxiredoxin III in human lung cancer. The Korean journal of internal medicine. 2011; 26:304-313.

22. Liu X, Feng R, Du L. The role of enoyl-CoA hydratase short chain 1 and peroxiredoxin 3 in PP2-induced apoptosis in human breast cancer MCF-7 cells. FEBS letters. 2010; 584:3185-3192.

23. Choi JH, Kim TN, Kim S, Baek SH, Kim JH, Lee SR, Kim JR. Overexpression of mitochondrial thioredoxin reductase and peroxiredoxin III in hepatocellular carcinomas. Anticancer research. 2002; 22:3331-3335.

24. Kim TH, Song J, Alcantara Llaguno SR, Murnan E, Liyanarachchi S, Palanichamy K, Yi JY, Viapiano MS, 
Nakano I, Yoon SO, Wu H, Parada LF, Kwon CH. Suppression of peroxiredoxin 4 in glioblastoma cells increases apoptosis and reduces tumor growth. PloS one. 2012; 7:e42818.

25. Ummanni R, Barreto F, Venz S, Scharf C, Barett C, Mannsperger HA, Brase JC, Kuner R, Schlomm T, Sauter G, Sultmann H, Korf U, Bokemeyer C, Walther R, Brummendorf TH, Balabanov S. Peroxiredoxins 3 and 4 are overexpressed in prostate cancer tissue and affect the proliferation of prostate cancer cells in vitro. Journal of proteome research. 2012; 11:2452-2466.

26. Wei Q, Jiang H, Xiao Z, Baker A, Young MR, Veenstra TD, Colburn NH. Sulfiredoxin-Peroxiredoxin IV axis promotes human lung cancer progression through modulation of specific phosphokinase signaling. Proceedings of the National Academy of Sciences of the United States of America. 2011; 108:7004-7009.

27. Gerard AC, Many MC, Daumerie C, Knoops B, Colin IM. Peroxiredoxin 5 expression in the human thyroid gland. Thyroid: official journal of the American Thyroid Association. 2005; 15:205-209.

28. Huang CF, Sun ZJ, Zhao YF, Chen XM, Jia J, Zhang WF. Increased expression of peroxiredoxin 6 and cyclophilin A in squamous cell carcinoma of the tongue. Oral diseases. 2011; 17:328-334.

29. Yun HM, Park KR, Lee HP, Lee DH, Jo M, Shin DH, Yoon DY, Han SB, Hong JT. PRDX6 promotes lung tumor progression via its GPx and iPLA2 activities. Free radical biology \& medicine. 2014; 69:367-376.

30. Jo M, Yun HM, Park KR, Hee Park M, Myoung Kim T, Ho Pak J, Jae Lee S, Moon DC, Park CW, Song S, Lee CK, Bae Han S, Tae Hong J. Lung tumor growth-promoting function of peroxiredoxin 6. Free radical biology \& medicine. 2013; 61C:453-463.

31. Bakiri L, Matsuo K, Wisniewska M, Wagner EF, Yaniv M. Promoter specificity and biological activity of tethered AP-1 dimers. Molecular and cellular biology. 2002; 22:4952-4964.

32. van Dam H, Castellazzi M. Distinct roles of Jun: Fos and Jun: ATF dimers in oncogenesis. Oncogene. 2001; 20:2453-2464.

33. Shaulian E, Karin M. AP-1 as a regulator of cell life and death. Nature cell biology. 2002; 4:E131-136.

34. Karamouzis MV, Konstantinopoulos PA, Papavassiliou AG. The activator protein-1 transcription factor in respiratory epithelium carcinogenesis. Molecular cancer research: MCR. 2007; 5:109-120.

35. Ma J, Zhang Z, Zhang L. [Expression of NF-kappa B and AP-1 in non-small cell lung cancer]. Zhongguo fei ai za zhi $=$ Chinese journal of lung cancer. 2005; 8:440-443.

36. Tichelaar JW, Yan Y, Tan Q, Wang Y, Estensen RD, Young MR, Colburn NH, Yin H, Goodin C, Anderson MW, You M. A dominant-negative c-jun mutant inhibits lung carcinogenesis in mice. Cancer prevention research. 2010; 3:1148-1156.
37. Zhou RJ, Shi Z, Zhou K, Wang HD, Zhang GQ, Li XT, $\mathrm{Xu}$ JP. Decreased SARI expression predicts poor prognosis of Chinese patients with non-small cell lung cancer. International journal of clinical and experimental pathology. 2013; 6:2056-2063.

38. Hess A, Wijayanti N, Neuschafer-Rube AP, Katz N, Kietzmann T, Immenschuh S. Phorbol ester-dependent activation of peroxiredoxin I gene expression via a protein kinase C. Ras, p38 mitogen-activated protein kinase signaling pathway. The Journal of biological chemistry. 2003; 278:45419-45434.

39. Ruan Y, Yao L, Zhang B, Zhang S, Guo J. Anti-inflammatory effects of Neurotoxin-Nna, a peptide separated from the venom of Naja naja atra. BMC complementary and alternative medicine. 2013; 13:86.

40. Gomes A, Bhattacharya S, Chakraborty M, Bhattacharjee P, Mishra R, Gomes A. Anti-arthritic activity of Indian monocellate cobra (Naja kaouthia) venom on adjuvant induced arthritis. Toxicon: official journal of the International Society on Toxinology. 2010; 55:670-673.

41. Shen J, He J, Tang X, Han R, Li R, Xu C, Wu Y. [Role of autophagy on cobrotoxin induced cell death of A549]. Zhongguo fei ai za zhi $=$ Chinese journal of lung cancer. 2013; 16:339-344.

42. Son DJ, Park MH, Chae SJ, Moon SO, Lee JW, Song HS, Moon DC, Kang SS, Kwon YE, Hong JT. Inhibitory effect of snake venom toxin from Vipera lebetina turanica on hormone-refractory human prostate cancer cell growth: induction of apoptosis through inactivation of nuclear factor kappaB. Molecular cancer therapeutics. 2007; 6:675-683.

43. Song JK, Jo MR, Park MH, Song HS, An BJ, Song MJ, Han SB, Hong JT. Cell growth inhibition and induction of apoptosis by snake venom toxin in ovarian cancer cell via inactivation of nuclear factor kappaB and signal transducer and activator of transcription 3. Archives of pharmacal research. 2012; 35:867-876.

44. Park MH, Jo M, Won D, Song HS, Han SB, Song MJ, Hong JT. Snake venom toxin from Vipera lebetina turanica induces apoptosis of colon cancer cells via upregulation of ROS- and JNK-mediated death receptor expression. BMC cancer. 2012; 12:228.

45. Kollipara PS, Won do H, Hwang CJ, Jung YY, Yoon HS, Park MH, Song MJ, Song HS, Hong JT. Enhanced AntiCancer Effect of Snake Venom Activated NK Cells on Lung Cancer Cells by Inactivation of NF-kappaB. Biomolecules \& therapeutics. 2014; 22:106-113.

46. Park MH, Son DJ, Kwak DH, Song HS, Oh KW, Yoo HS, Lee YM, Song MJ, Hong JT. Snake venom toxin inhibits cell growth through induction of apoptosis in neuroblastoma cells. Archives of pharmacal research. 2009; 32:1545-1554.

47. Siigur E, Aaspollu A, Siigur J. Sequence diversity of Vipera lebetina snake venom gland serine proteinase homologsresult of alternative-splicing or genome alteration. Gene. 2001; 263:199-203. 
48. Park MH, Song HS, Kim KH, Son DJ, Lee SH, Yoon DY, Kim Y, Park IY, Song S, Hwang BY, Jung JK, Hong JT. Cobrotoxin inhibits NF-kappa B activation and target gene expression through reaction with NF-kappa B signal molecules. Biochemistry. 2005; 44:8326-8336.

49. Jo M, Yun HM, Park KR, Park MH, Lee DH, Cho SH, Yoo HS, Lee YM, Jeong HS, Kim Y, Jung JK, Hwang BY, Lee MK, Kim ND, Han SB, Hong JT. Anti-cancer effect of thiacremonone through down regulation of peroxiredoxin 6 . PloS one. 2014; 9:e91508.

50. Pak JH, Choi WH, Lee HM, Joo WD, Kim JH, Kim YT, Kim YM, Nam JH. Peroxiredoxin 6 overexpression attenuates cisplatin-induced apoptosis in human ovarian cancer cells. Cancer investigation. 2011; 29:21-28.

51. Walsh B, Pearl A, Suchy S, Tartaglio J, Visco K, Phelan SA. Overexpression of Prdx6 and resistance to peroxide-induced death in Hepa1-6 cells: Prdx suppression increases apoptosis. Redox report: communications in free radical research. 2009; 14:275-284.

52. Ren L, Yang HY, Choi HI, Chung KJ, Yang U, Lee IK, Kim HJ, Lee DS, Park BJ, Lee TH. The role of peroxiredoxin $\mathrm{V}$ in (-)-epigallocatechin 3-gallate-induced multiple myeloma cell death. Oncology research. 2011; 19:391-398.

53. Bast A, Fischer K, Erttmann SF, Walther R. Induction of peroxiredoxin I gene expression by LPS involves the Src/ $\mathrm{PI} 3 \mathrm{~K} / \mathrm{JNK}$ signalling pathway. Biochimica et biophysica acta. 2010; 1799:402-410.

54. Chhunchha B, Fatma N, Bhargavan B, Kubo E, Kumar A, Singh DP. Specificity protein, Spl-mediated increased expression of Prdx6 as a curcumin-induced antioxidant defense in lens epithelial cells against oxidative stress. Cell death \& disease. 2011; 2:e234.

55. Jiang $\mathrm{H}, \mathrm{Wu} \mathrm{L}$, Mishra M, Chawsheen HA, Wei Q. Expression of peroxiredoxin 1 and 4 promotes human lung cancer malignancy. American journal of cancer research. 2014; 4:445-460.
56. Perez-Sala D, Cernuda-Morollon E, Canada FJ. Molecular basis for the direct inhibition of AP-1 DNA binding by 15-deoxy-Delta 12, 14-prostaglandin J2. The Journal of biological chemistry. 2003; 278:51251-51260.

57. Rishi V, Oh WJ, Heyerdahl SL, Zhao J, Scudiero D, Shoemaker RH, Vinson C. 12 Arylstibonic acids that inhibit the DNA binding of five B-ZIP dimers. Journal of structural biology. 2010; 170:216-225.

58. Gerdes MJ, Myakishev M, Frost NA, Rishi V, Moitra J, Acharya A, Levy MR, Park SW, Glick A, Yuspa SH, Vinson C. Activator protein-1 activity regulates epithelial tumor cell identity. Cancer research. 2006; 66:7578-7588.

59. Frolkis I, Klein Y, Locker C, Adi N, Dahan E, Uretzsky G, Shapira I, Sorkine P. Vipera aspis venom reduces lethality and down-regulates tumor necrosis factor-alpha in a rat model of LPS-induced sepsis. Cytokine. 2010; 49:319-324.

60. Badr G, Sayed D, Maximous D, Mohamed AO, Gul M. Increased susceptibility to apoptosis and growth arrest of human breast cancer cells treated by a snake venom-loaded silica nanoparticles. Cellular physiology and biochemistry: international journal of experimental cellular physiology, biochemistry, and pharmacology. 2014; 34:1640-1651.

61. Lee HL, Park MH, Hong JE, Kim DH, Kim JY, Seo HO, Han SB, Yoon JH, Lee WH, Song HS, Lee JI, Lee US, Song MJ, Hong JT. Inhibitory effect of snake venom toxin on NF-kappaB activity prevents human cervical cancer cell growth via increase of death receptor 3 and 5 expression. Arch Toxicol. 2014; ahead of print.

62. Bennacef-Heffar N, Laraba-Djebari F. Evaluation of the effect of gamma rays on the venom of Vipera lebetina by biochemical study. Canadian journal of physiology and pharmacology. 2003; 81:1110-1117.

63. Pierce BG, Wiehe K, Hwang H, Kim BH, Vreven T, Weng Z. ZDOCK server: interactive docking prediction of protein-protein complexes and symmetric multimers. Bioinformatics. 2014; 30:1771-1773. 